\title{
Fusarium Wilt (Fusarium oxysporum f. sp. niveum) of Watermelon'
}

\author{
Pamela Roberts, Nicholas Dufault, Robert Hochmuth, Gary Vallad, and Mathews Paret ${ }^{2}$
}

\section{Introduction}

Watermelon is an important US vegetable crop. The USDA Economic Research Service reported over 113,000 acres of watermelon in the United States in 2017, producing 40 million pounds of product. While watermelons are grown across the United States, most production occurs in Florida, Georgia, Texas, and California, accounting for approximately $69 \%$ of US production. The average US watermelon yield per acre in 2014 was 31,800 pounds. In terms of vegetable production, watermelon is one of the three top crops produced in the United States, along with onions and head lettuce. Seedless watermelon varieties are experiencing increasing demand; the share of seedless watermelon in total US watermelon shipments increased from 51\% in 2003 to nearly $85 \%$ in 2014 . Seedless varieties, typically started as transplants rather than from direct seeding, require more intensive management, with the cost differences generally visible at the retail level. US cash receipts for watermelons was $\$ 578.8$ million in 2016 .

Fusarium wilt of watermelon is one of the most serious and difficult diseases to manage and occurs in most production regions worldwide. The fungus can be seedborne and has great longevity in the soil, allowing infested soil to also serve as a source of infection.

\section{Causal Organism}

Fusarium wilt of watermelon is caused by the fungus Fusarium oxysporum f. sp. niveum (FON) (Figure 1). The pathogen is host-specific to watermelon and will not cause disease on other closely related cucurbits or noncucurbit hosts. Four races, designated $0,1,2$, and 3, have been described, and although race 1 is the mostly widely distributed, race 2 is emerging in many production regions. Race 3 of FON was recently identified (Zhou et al. 2010; Amaradasa et al. 2018). Each of the four races is found in Florida. Races of FON are determined by their reaction to a set of watermelon genotypes/lines that vary in their level of resistance and show a differential reaction (Table 1) (Martyn and Netzer 1991; Zhou and Everts 2003).

\section{Signs and Symptoms}

The first field symptoms of Fusarium wilt of watermelon plants are dull gray-green leaves and wilting during the hottest part of the day. Wilted plants commonly recover at night, but over time (2 to 5 days) wilt symptoms become permanent. Wilt symptoms may appear on one or more runners (Figure 2). Infected plants eventually collapse and die. The spatial distribution of infected plants in the field often appears as clusters or "hot spots" (Figure 3). Brownto-reddish discoloration of the vascular tissues in the plant crown and runners is diagnostic for this disease. Plant roots

1. This document is PP352, one of a series of the Plant Pathology Department, UF/IFAS Extension. Original publication date October 2019. Visit the EDIS website at https://edis.ifas.ufl.edu for the currently supported version of this publication.

2. Pamela Roberts, professor, Plant Pathology Department, UF/IFAS Southwest Florida Research and Education Center; Nicholas Dufault, associate professor, Plant Pathology Department; Robert Hochmuth, Extension agent IV—vegetables, and center director, UF/IFAS Suwannee Valley Agricultural Extension Center; Gary Vallad, associate professor, Plant Pathology Department, UF/IFAS Gulf Coast Research and Education Center; and Mathews Paret, associate professor, Plant Pathology Department, UF/IFAS North Florida Research and Education Center; UF/IFAS Extension, Gainesville, FL 32611.

The Institute of Food and Agricultural Sciences (IFAS) is an Equal Opportunity Institution authorized to provide research, educational information and other services

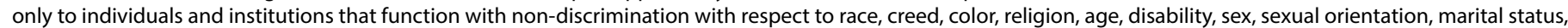

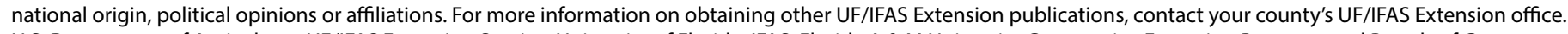
U.S. Department of Agriculture, UF/IFAS Extension Service, University of Florida, IFAS, Florida A \& M University Cooperative Extension Program, and Boards of County Commissioners Cooperating. Nick T. Place, dean for UF/IFAS Extension. 
may appear white and healthy early in the infection (Figure 4). However, in later stages of the disease, the entire root may become dark brown, and a soft rot may develop near the crown. Infected seedlings in transplant houses may rapidly wilt and die without exhibiting the typical vascular discoloration (Figure 5).

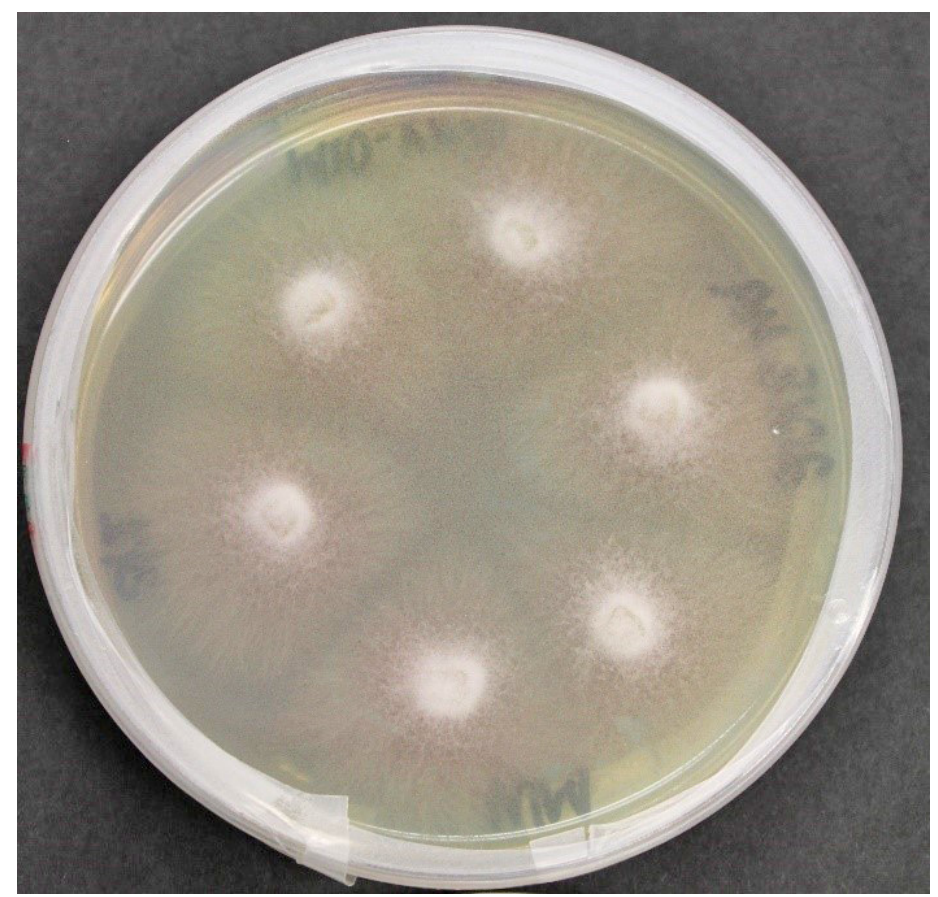

Figure 1. Growth of the fungus Fusarium oxysporum f. sp. niveum on artificial media in lab petri plate.

Credits: K. Hendricks, UF/IFAS

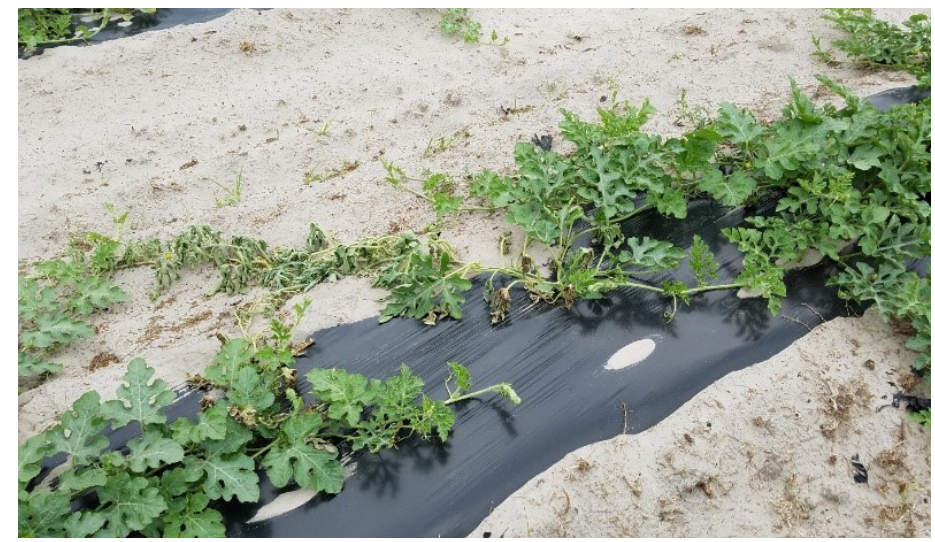

Figure 2. Watermelon plant exhibiting typical symptoms of Fusarium wilt known as "sectoring," where one vine is wilted while another remains asymptomatic on the same plant.

Credits: N. Dufault, UF/IFAS

\section{Disease Cycle}

FON produces highly resilient spores that can survive in the soil for extended periods of time (up to 20 years) even in absence of its host. The pathogen can be spread to new areas on seed or in soil transported by equipment, surface water, and humans. Because FON is seed-transmitted, outbreaks of Fusarium wilt can occur on transplants in production houses, and the pathogen can spread within transplant beds. Infected but asymptomatic transplants are an important source of field infection. FON is mostly soilborne, meaning that it does not produce aerial spores; however, there is evidence for movement from infected plants to distant plants, particularly in the transplant setting.

Conditions that favor Fusarium wilt are moderate soil temperatures $\left(77^{\circ} \mathrm{F}-80^{\circ} \mathrm{F}\right)$ and wet weather. Light and sandy soils and acidic soils ( $\mathrm{pH} 5.5$ to 6.5) contribute to disease severity.

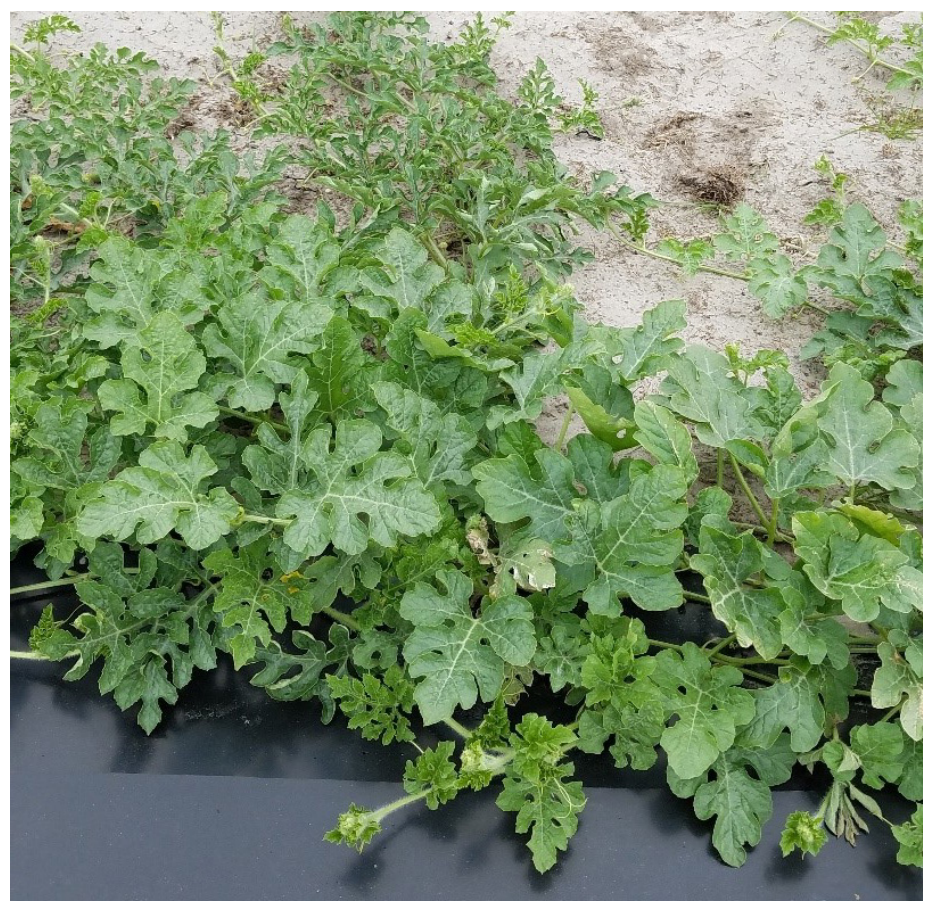

Figure 3. Watermelon field with reduced plant stand due to Fusarium wilt.

Credits: N. Dufault, UF/IFAS

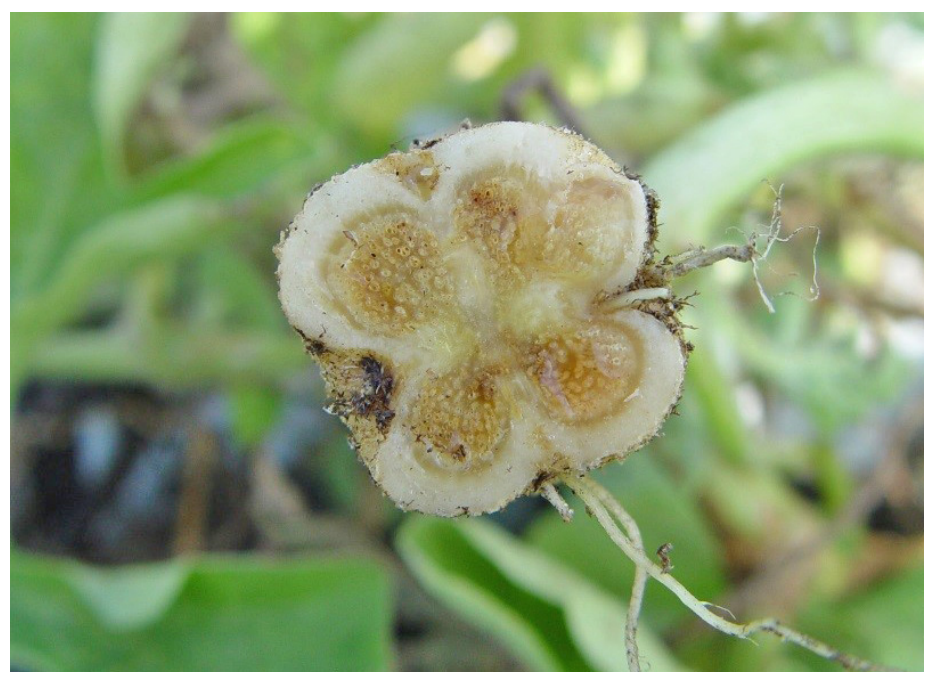

Figure 4. Vascular discoloration in crown is diagnostic for Fusarium wilt on watermelon.

Credits: N. Dufault, UF/IFAS 


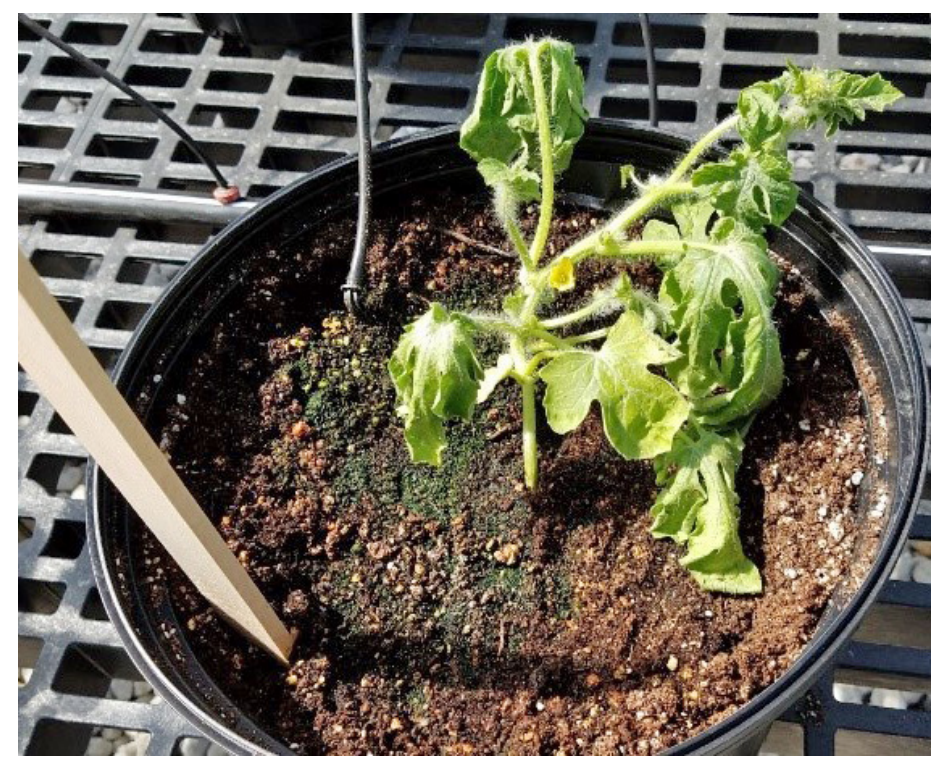

Figure 5. Transplanted seedling in the greenhouse exhibiting wilting and yellowing due to infection with the Fusarium wilt fungus. Credits: N. Dufault, UF/IFAS

\section{Management}

\section{Cultural Controls}

\section{HOST RESISTANCE}

Some commercial varieties have resistance to some of the FON races. Most are resistant to race 0 and many are resistant to race 1 . However, only a few pollinators have resistance to race 2 , and no commercial varieties are resistant to race 3 (Kemble et al. 2018). Because there may be a mixed population of FON (more than one race) in watermelon fields, it is recommended to plant varieties with resistance when possible.

\section{SANITATION IN GREENHOUSE AND FIELD}

It is imperative to start with disease-free transplants. Despite the inoculum being seedborne, removing infected plant trays and adjacent trays is the best way to reduce occurrence and spread of the inoculum throughout the greenhouse. Seedling symptoms can be difficult to differentiate from other common seedling diseases, so proper diagnosis is essential for management. New or sterilized transplant trays should be used. In the transplant house, clean and sanitize benches and all equipment. For additional information on greenhouse sanitation, see EDIS publication HS714, Commercial Transplant Production in Florida, at https://edis.ifas.ufl.edu/cv104.

\section{GRAFTED PLANTS}

Grafted plants in which the watermelon scions are grafted onto resistant squash or bottle-gourd rootstocks are gaining popularity due to increased quality and availability of grafted plants (Figure 6) (Keinath and Hassel 2014).
These rootstocks are resistant to races 1 and 2 (Kemble et al. 2018), and preliminary research has indicated this resistance will be sustained with race 3 .

\section{CROP ROTATION}

Crop rotation and fallow periods remain an important management strategy despite the ability of FON to survive for such long periods of time in the soil. The goal of crop rotation is to reduce the inoculum in the soil. A study of FON populations over time in fallow fields found that levels were reduced by $20 \%, 40 \%$, and $50 \%$ after 1,2 , and 3 years of fallow, respectively (Wu et al. 2013). The common recommendation is watermelons should be planted in a field only 5 to 7 years after a previous watermelon crop.

\section{DELAYED PLANTINGS}

Delaying planting by 1 to 4 weeks can reduce Fusarium wilt disease incidence. This management method does delay harvest by 5 to 7 days for a 4-week delay in planting, but this delay is highly dependent on growing degree-days (a heat index that can be used to predict when a crop will reach maturity) after transplanting and the variety.

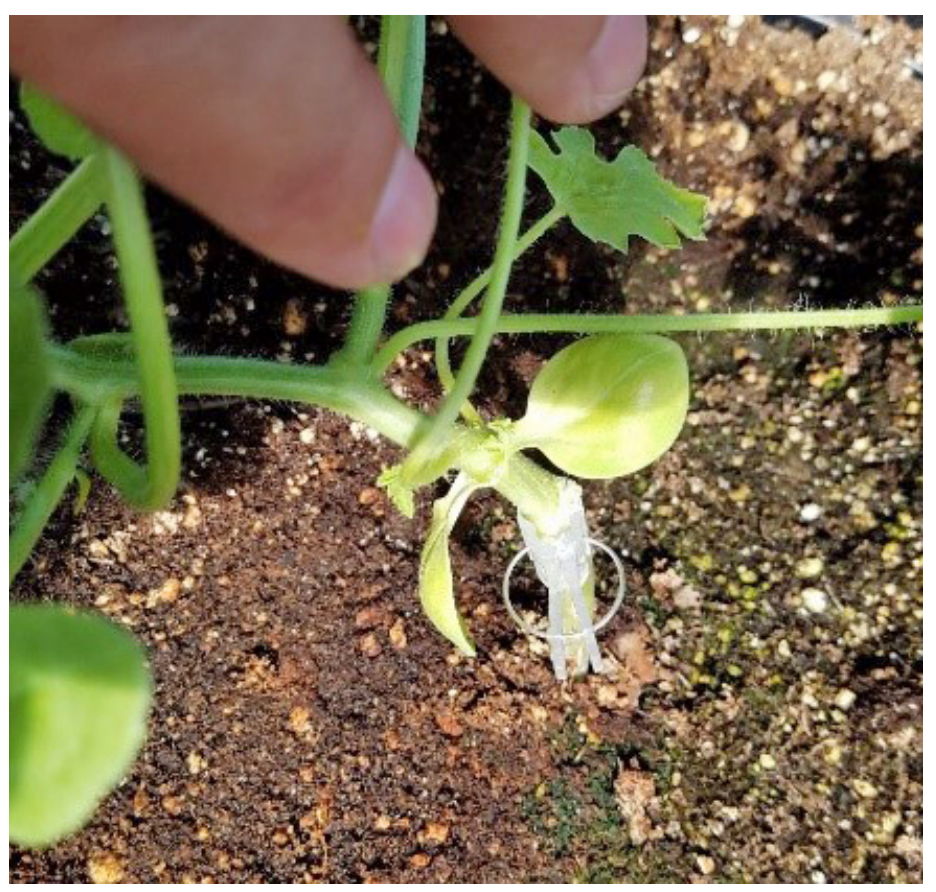

Figure 6. Watermelon scion grafted onto Fusarium wilt-resistant rootstock.

Credits: N. Dufault, UF/IFAS

\section{Chemical Control FUMIGATION}

Soil fumigation may lower inoculum in the soil. Recent research on Fusarium wilt management in watermelon conducted by UF/IFAS has focused on soil fumigant choices, placement, and plastic mulch type (totally impermeable 
films). For a current list of fumigants labeled for cucurbit crops in Florida, please visit HS725, Cucurbit Production, in the Vegetable Production Handbook of Florida (http://edis. ifas.ufl.edu/cv123).

\section{FUNGICIDES}

Fungicides alone are generally not effective in controlling Fusarium wilt but may help to reduce the level of disease damage to plants in the field. For information on recommended fungicides and their use, see HS725, Cucurbit Production, in the Vegetable Production Handbook of Florida (http://edis.ifas.ufl.edu/cv123).

\section{References}

Amaradasa, B. S., K. Beckham, N. Dufault, T. Sanchez, T. S. Ertek, F. Iriarte, M. Paret, and P. Ji. 2018. "First Report of Fusarium oxysporum f. sp. niveum Race 3 Causing Wilt of Watermelon in Florida, U.S.A." Plant Disease 102: 1029.

Keinath, A. P., and R. L. Hassell. 2014. "Suppression of Fusarium Wilt Caused by Fusarium oxysporum f. sp. niveum Race 2 on Grafted Triploid Watermelon." Plant Disease 98: 1326-1332.
Kemble, J. M., I. M. Meadows, K. M. Jennings, and J. F. Walgenbach, eds. 2018. Vegetable Crop Handbook for the Southeastern United States. Southeastern Vegetable Extension Workers Group. https://www.growingproduce.com/ southeasternvegetablecrophandbook/

Martyn, R. D., and D. Netzer. 1991. "Resistance to Races 0,1, and 2 of Fusarium Wilt of Watermelon in Citrullus sp. PI-296341-FR." Hortscience 26: 429-432.

Wu, H.-S., Z.-Q. Gao, X.-D. Zhou, X. Shi, M.-Y. Wang, X.-X. Shang, Y.-D. Liu, D.- L. Gu, and W.-Z. Wang. 2013. "Microbial Dynamics and Natural Remediation Patterns of Fusarium-Infested Watermelon Soil under 3-yr of Continuous Fallow Condition." Soil Use Management 29: 220-229.

Zhou, X. G., and K. L. Everts. 2003. "Races and Inoculum Density of Fusarium oxysporum f. sp. niveum in Commercial Watermelon Fields in Maryland and Delaware." Plant Disease 87: 692-698.

Zhou, X. G., K. L. Everts, and B. D. Bruton. 2010. "Race 3, a New and Highly Virulent Race of Fusarium oxysporum $\mathrm{f}$. sp niveum Causing Fusarium Wilt in Watermelon." Plant Disease 94: 92-98.

Table 1. Race of Fusarium oxysporum f. sp. niveum is determined by Susceptible (S) or Resistant (R) reaction to a set of watermelon differentials.

\begin{tabular}{|l|c|c|c|}
\hline \multicolumn{1}{|c|}{ Cultivar } & Race 0 & Race 1 & Race 2 \\
\hline Sugar Baby, Black Diamond & S & S & S \\
\hline Charleston Gray, Allsweet, Dixielee & R & S & S \\
\hline Calhoun Gray & R & R & S \\
\hline Pl-296341-FR & R & R & R \\
\hline
\end{tabular}

